\title{
The Effect of Organizational Culture, Achievement Motivation and Job Satisfaction on the Performance of Teachers of SMP Negeri in North Tapanuli
}

\author{
Torus Manuntun \\ Post Graduate Program, \\ Universitas Negeri Medan, \\ Medan, Indonesia \\ tmanuntun@gmail.com
}

\begin{abstract}
This research aims to study: The Effect of Organizational Culture, Achievement Motivation and Job Satisfaction on the Performance of Teachers of SMP Negeri in North Tapanuli. This study aims to determine, The Effect of Organizational Culture on Achievement Motivation, Organizational Culture on Job Satisfaction, and the Effect of Organizational Culture, Achievement Motivation and Job Satisfaction on Performance, Teachers of Public Middle Schools in North Tapanuli Regency. The research method used is a quantitative method and a path analysis approach. The population is all 2018 PNS teachers as many as 614 teachers. Total sample of 222 teachers (according to Isaac and Michael's table). Before testing the hypothesis, the analysis requirements test is done, namely the Data Normality Test and Linearity Test. The research findings show that organizational culture has a direct positive effect on achievement motivation, organizational culture has a positive direct effect on job satisfaction, organizational culture has a positive direct effect on performance, achievement motivation has a positive direct effect on performance, and job satisfaction has a positive direct effect on performance. Based on research findings the greatest influence on performance is Achievement Motivation, then Organizational Culture and Job Satisfaction. So, to improve the performance of teachers of State Junior High Schools in North Tapanuli Regency can be done by increasing the Teacher Achievement Motivation, Organizational Culture and Job Satisfaction.
\end{abstract}

Keywords- Organizational Culture, Achievement Motivation, Job Satisfaction, Performance.

\section{INTRODUCTION}

School is a place to nurture and develop the potential it has. The school program is the most important factor in organizing activities related to developing the potential of the school.

So from the above problems, schools need to improve teacher performance through teacher commitment, organizationalclimate, organizational culture, work motivation, job satisfaction, teacher competency improvement, headmaster's leadership so that school programs can be realized in accordance with their potential. Many factors influence and support TEACHER PERFORMANCE, including the influence of Organizational Culture, Achievement Motivation and Job Satisfaction.

\section{LITERATURE REVIEW}

\section{A. The Organizational culture}

The Organizational culture is: " a set of symbols, ceremoniies, and myths that communicate the underlying values and beliefs of that organization to its employees". Based on several studies of organizational culture at school can affect the performance of a teacher, as according to [1-5] said that school culture has a direct impact on social development, emotional security and work outcomes as well as attributes and beliefs that shape school culture that can be changed or changed, and members' self-confidence will be the basis for adjusting the work environment, which can influence what is perceived and defined as the cultural environment, school performance and service quality. Based on some of the opinions above, it can be argued that organizational culture is a pattern of shared values, beliefs, and assumptions that are considered to be the right way to think and act in an organization created by certain groups of the best experience while working in the organization.

\section{B. The Achievement motivation}

Motivation can be divided into 2 forms; intrinsic motivation and extrinsic motivation. [6-10]. Internal Motivation: motivation that grows from within a person without being influenced by others to do something to achieve goals. External motivation: motivation that comes from outside oneself with the hope of achieving something that can benefit him. Teacher achievement motivation is an encouragement from within the teacher to do better than what has been made (achieved) before, with indicators: willingness to progress, work well, accept challenges, accept personal responsibility, and succeed. Abdul, R (2017:54). Achievement motivation is the encouragement from within the teacher to do better than what has been made (achieved) before, with indicators: willingness to progress, work well, accept 
challenges, accept personal responsibility so as to produce satisfying work to achieve success.

\section{The Job satisfaction}

The Job satisfaction is largely determined by comparison: what work provides for them and what they give for work.. The job satisfaction is an individual's assessment or evaluation of whether or not he likes a job and its relationship with the workplace environment that can affect future performance. Based on the description above, it can be formulated several indicators of job satisfaction, namely: (a) salary satisfaction, (b) promotion satisfaction, (c) social satisfaction, (d) supervision satisfaction, (e) job satisfaction, (f) status satisfaction, (g) work colleague satisfaction, and (h) work environment satisfaction

\section{The Performance}

The performance is the result of quality and quantity of work achieved by an employee in carrying out their duties in accordance with the responsibilities given to him [11-13]. The performance is a job that requires time and responsibility where the results can be measured significantly according to established standards.

\section{DATA COLLECTION}

The instruments used in this study were teacher performance questionnaire, organizational culture questionnaire, achievement motivation questionnaire and job satisfaction questionnaire. The instrument used was in the form of a questionnaire. This instrument is used to measure the value of the variable under study.

Sampling from the study population was carried out using the Probability Sampling technique, according to [14-16], Probability Sampling is a sampling technique that provides equal opportunities for each element (members) The assumption of normality is a prerequisite for proceeding to further testing. Analyzes were performed with multiple linear regression and hypothesis testing was performed at a significance level of 0.05 . The implications of the findings of this study were then discussed.

\section{RESULT AND DISCUSSION}

The Normality test is carried out by the Kolmogorov Smirno formula with SPSS version 20. Data is normally distributed. Normality test scores for Organizational Culture, Achievement Motivation, Job Satisfaction and Teacher Performance are $0.626,0.535,0.829,0.293$ for $\mathrm{n}=222$.

\section{A. The Effect of Organizational Culture on Achievement Motivation}

The results of the calculation of the path analysis obtained path coefficient value of the influence of Organizational Culture on Achievement Motivation at $21=0.333$ with a coefficient value of tcount $=5.243$ and a significance value $<0.05$ or $\mathrm{t}$-value greater than the value of the table $(\alpha=0.05)=$ 1, 96 then Ho is rejected and $\mathrm{Ha}$ is accepted. Thus, it was concluded that Organizational Culture had a direct positive effect on the Achievement Motivation behavior of SMP Negeri teachers in North Tapanuli

\section{B. The Effect of Organizational Culture on Job Satisfaction}

The results of the calculation of path analysis obtained path coefficient value of the influence of Organizational Culture on Job Satisfaction at $31=0.393$ with a coefficient value of tcount $=6.334$ and a significance value $<0.05$ or tcount value greater than the value of the table $(\alpha=0.05)=1$, 96 then $\mathrm{Ho}$ is rejected and $\mathrm{Ha}$ is accepted. Thus, it was concluded that Organizational Culture had a direct positive effect on the behavior of Job Satisfaction of Public Middle School teachers in North Tapanuli.

\section{The Effect of Organizational Culture on Performance}

The results of the calculation of the path analysis obtained the path coefficient value of the influence of Organizational Culture on Performance at $41=0.233$ with the coefficient value of tcount $=3.627$ and the significance value $<0.005$ or tcount value greater than the value of the table $(\alpha=0.05)=$ 1.96 then Ho rejected and Ha accepted. Thus, it was concluded that Organizational Culture had a direct positive effect on the behavior of the performance of teachers of SMP Negeri in North Tapanuli.

\section{The Effect of Achievement Motivation on Performance}

The results of the calculation of the path analysis obtained path coefficient value of Achievement Motivation on Performance at $\quad 42=0.265$ with a coefficient value of tcount $=4.015$ and a significance value $<0.05$ or $\mathrm{t}$-value greater than the value of the table $(\alpha=0.05)=1.96$ then Ho is rejected and $\mathrm{Ha}$ is accepted. Thus, it was concluded that Achievement Motivation had a direct positive effect on the behavior of the performance of state junior high school teachers in North Tapanuli.

\section{E. The Effect of Job Satisfaction on Performance}

The results of the calculation of the path analysis obtained path coefficient value of Job Satisfaction influence on Performance at $\quad 43=0.170$ with a coefficient value of $t=$ 2.503 and a significance value $<0.05$ or $t$-value greater than the value of the table $(\alpha=0.05)=1.96$ then Ho is rejected and $\mathrm{Ha}$ is accepted. Thus, it was concluded that Job Satisfaction had a direct positive effect on the behavior of the performance of the State Junior High School teachers in North Tapanuli.

\section{CONCLUSION}

The findings, explanations and results of data analysis and discussion of the results of research that have been carried out, concluded that:

a. There is a positive direct effect between organizational culture on achievement motivation. This shows that the improvement of school organizational culture resulted in an increase in the achievement motivation of public junior high school teachers in North Tapanuli. 
b. There is a positive direct effect between the influence of organizational culture on job satisfaction. This shows that the improvement of school organizational culture results in an increase in job satisfaction of teachers of state junior high schools in North Tapanuli.

c. There is a positive direct effect between the influence of organizational culture on performance. This shows that improving the culture of school organizations does not result in an increase in the performance of state junior high school teachers in North Tapanuli.

d. There is a positive direct effect between the effect of achievement motivation on performance. This shows that an increase in teacher achievement motivation does not result in an increase in the performance of teachers of SMP Negeri in North Tapanuli.

e. There is a positive direct effect between the effect of job satisfaction on performance. This shows that the increase in teacher job satisfaction has resulted in an increase in the performance of teachers of SMP Negeri in North Tapanuli.

\section{References}

[1] G. Eason, B. Noble, and I.N. Sneddon, "On certain integrals of Ambarita, Biner., Sukarman, Purba, \& Ambarita, C, F. (2016). Perilaku dan Konflik Dalam Organisasi. Bandung : Alfabeta.

[2] Ansory, H, A., Indrasari, M (2018). Manajemen Sumber Daya Manusia. Sidoarjo : Indomedia Pustaka.

[3] Hervie, D.M dan Winful, C.E. (2018). Enhancing Teachers' Performance through Training and Development in Ghana Education Service (A Case Study of Ebenezer Senior High School), Journal of Human Resource Management. Vol. 6, No. 1, 2018, pp. 1-8
[4] Indrasari, M. (2017). Kepuasan Kerja dan Kinerja Karyawan : Tinjauan dari Dimensi Iklim Organisasi, Kreativitas Individu, dan Karakteristik Pekerjaan. Sidoarjo : Indomedia Pustaka.

[5] Kamus Pusat Bahasa. (2008). Kamus Bahasa Indonesia. Jakarata : Pusat Bahasa Departemen Pendidikan Nasional

[6] Kusumaningtyas, A., Setyawati, E. (2015). Teacher Performance of The State Vocational High SchoolTeachers in Surabaya, International Journal of Evaluation and Research in Education (IJERE). Vol.4, No.2, June 2015, pp. 76 83

[7] Nigama, K., Selvabaskar, S., Surulivel, S.T., Alamelu, R., Joice, U.D

[8] Pongoh, S. (2014). The Effect of Principal Leadership and Achievement Motivation on Teaching Competence of Public School Teacher in Manado City. Journal of Education and Practice. Vol.5, No.1, 2014.

[9] Priyono. (2010). Manajemen Sumber Daya Manusia. Sidoarjo: Zifatama Publishe.

[10] Qamari,I.N., Dewayani, J., Frianto, A., Nugroho, M., Mulyotomo, E., Priyotomo, R.S. (2014). Telaah Buku Perilaku Organisasi dan Pengembangan Organisasi. Yogyakarta: Lembaga Penelitian, Publikasi, dan Pengabdian Pada Masyarakat Universitas Muhammadiyah Yogyakarta

[11] Sugiyono. (2010). Statistik Untuk Penelitian. Bandung : Alfabeta

[12] Sugiyono. (2018). Metode Penelitian Pendidikan: Pendekatan Kuantitatif, Kualitatif, dan R\&D. Bandung: Alfabeta

[13] Suharningsih \& Murtedjo. Role of Organizational Culture on the Performance Primary School Teachers. Journal of Education and Learning; Vol. 6, No. 1; 2017

[14] Tahir, A. (2014). Buku Ajar: Perilaku Organisasi. Yogyakarta: Deepublish

[15] Tiwai, T., Kambey, E., Naharia, O., dan Senduk, J (2018). Effect of supervision of headmaster learning and achievement motivation on working climate at public junior high school. International Journal of Advanced Educational Research. Volume 3; Issue 3; May 2018; Page No. 04-10

[16] Triwahyuni, L. (2014). The Effect of Organizational Culture, Transformational Leadership and Self- Confidence to Teachers' Performance. International Journal of Managerial Studies and Research (IJMSR. Volume 2, Issue 10, November 2014, PP 156-165 